\title{
The detection of 3 ambiguous type 2 vaccine-derived polioviruses (VDPV2s) in Uganda
}

\author{
Mary Bridget Nanteza ${ }^{1 *} \mathbb{D}$, Barnabas Bakamutumaho1, Annet Kisakye², Prossy Namuwulya', Henry Bukenya', \\ Edson Katushabe ${ }^{2}$, Josephine Bwogi ${ }^{1}$, Charles Rutebarika Byabamazima ${ }^{3}$, Raffaella Williams ${ }^{4,5}$ and Nicksy Gumede ${ }^{6}$
}

\begin{abstract}
Background: The Oral Polio Vaccine (OPV or Sabin) is genetically unstable and may mutate to form vaccinederived polioviruses (VDPVs).

Methods: In 2014, two VDPVs type 2 were identified during routine surveillance of acute flaccid paralysis (AFP) cases. Consequently, a retrospective VDPV survey was conducted to ensure that there was no circulating VDPV in the country. All Sabin poliovirus isolates identified in Uganda 6 months before and 6 months after were rescreened; Sabin 1 and 3 polioviruses were re-screened for Sabin 2 and Sabin 2 polioviruses were re-screened for VDPVs type 2. The Poliovirus rRT-PCR ITDNDPV 4.0 assay and sequencing were used respectively.

Results: The first two VDPVs type2 were identified in Eastern Uganda and the third was identified during the survey from South-western Uganda. These regions had low OPV coverage and poor AFP surveillance indicators.

Conclusion: The retrospective VDPV survey was a useful strategy to screen for VDPVs more exhaustively. Supplementary surveillance methods need to be encouraged.
\end{abstract}

Keywords: Vaccine-derived poliovirus, Uganda, Poliovirus, Immunization

\section{Background}

VDPVs originate from OPV which has mutated in the gut. These mutant strains rarely cause outbreaks of paralytic poliomyelitis $[1,2]$ however such viruses can be culprits for major and prolonged outbreaks.

The poliovirus evolution usually occurs in unimmunized populations with low OPV coverage [3]. The poliovirus can continue to circulate uninterrupted for a long time. The lower the population immunity the longer the poliovirus is allowed to survive and the more it will replicate [2], mutate, and acquire wild poliovirus neuro-characteristics. Fully immunized populations are protected from VDPVs and wild poliovirus [4].

There are 3 serotypes of polioviruses; poliovirus type 1 (PV1), poliovirus type 2 (PV2), and poliovirus type 3 (PV3). The mutated OPV can be classified according to

\footnotetext{
* Correspondence: marybridgetnanteza@yahoo.com

${ }^{1}$ Uganda Virus Research Institute (UVRI), Plot 51 - 59 Nakiwogo Road, P. O.

Box 49, Entebbe, Uganda

Full list of author information is available at the end of the article
}

the diversity of the virus capsid protein 1(VP1). Poliovirus undergoes an evolution rate of approximately $1 \%$ per year, which results in $\sim 10$ nucleotide differences in the $903 \mathrm{nt}$. VP1. The poliovirus ribonucleic (RNA) polymerase enzyme has an error rate of 1 per 1000 nucleotides per round of replication $[5,6]$, and contributes to virus evolution. The normal period of poliovirus excretion is less than 3 months [7-9].

The mutated polioviruses are classified as vaccine-related polioviruses (VRPVs) when there is a VP1 sequence divergence from the reference Sabin polioviruses of $\leq 1 \%$ for Sabin 1 and 3, and $\leq 0.6 \%$ for Sabin 2 [2]. Sabin polioviruses showing VP1 divergence of $>1 \%$ for Sabin 1 and 3, and $>0$. $6 \%$ for Sabin 2 are classified as vaccine-derived polioviruses (VDPVs) [2]. A lower number of nucleotide differences has been considered for the VDPV type 2 because such mutants behaved like the wild type in DRC and Nigeria [10, 11]. Wild polioviruses are distinct and are not genetically linked to vaccine polioviruses $[12,13]$.

(c) The Author(s). 2018 Open Access This article is distributed under the terms of the Creative Commons Attribution 4.0 International License (http://creativecommons.org/licenses/by/4.0/), which permits unrestricted use, distribution, and reproduction in any medium, provided you give appropriate credit to the original author(s) and the source, provide a link to the Creative Commons license, and indicate if changes were made. The Creative Commons Public Domain Dedication waiver (http://creativecommons.org/publicdomain/zero/1.0/) applies to the data made available in this article, unless otherwise stated. 
VDPVs are classified into three categories; The first category are the circulating VDPVs (cVDPV) that are genetically linked and isolated from a) at least 2 individuals who may not be AFP cases but coming from different households or b) one individual and one or more environment samples or c) series of environmental samples from 2 or more sites or d) a single VDPV with documented evidence of circulation based on the genetic characteristics of the available VDPVs. The second category of VDPVs are the immune-deficiency-related VDPV (iVDPV). These are viruses isolated from persons with proven immunodeficiencies [14]. The third category are the ambiguous VDPV (aVDPV); these are isolates that are identified from individuals with or without AFP and who are not immune-compromised or from environmental samples without evidence of circulation. VDPVs reported as ambiguous VDPVs might later qualify to be iVDPV or cVDPV. The aVDPVs commonly occur in countries of low rates of polio vaccination coverage and could signal cVDPV emergence and gaps in immunization and surveillance activities [11].

cVDPVs are more transmissible and co-existence with OPV viruses may favor cVDPVs to become endemic while the OPV viruses get eliminated [15]. Without effective vaccination response to boost population immunity, VDPVs manifest with prolonged outbreaks $[2,16]$. Sabin 2 is more transmissible than Sabin type 1 and 3 $[2,17]$ and has been reported to circulate longer.

From 2000 to 2015 cVDPV2 have been reported from 21 countries [18]. These were associated with low AFP surveillance and inadequate immunization coverage. Immunodeficiency-related VDPV2 and VDPV3 were detected in Iran in 1995, 2005, 2007 [19] and other several places [20-22]. We report three aVDPVs type 2 that were sampled in 2014; two were detected during the routine AFP surveillance in 2014 and one was detected during a follow-up VDPV re-screening survey in 2016.

\section{Methods}

Identification of VDPVs using the routine AFP surveillance system

Through the routine national AFP surveillance system, two VDPVs that were contacts to two AFP cases from Kamuli and Kween were identified. One stool sample was collected from the contacts and was delivered to the laboratory in a cold chain. The AFP case investigation questionnaire for poliomyelitis was used to obtain the demographic, clinical, immunization, and social data for the AFP cases while a contact investigation questionnaire was used for the contacts. The virus culture of stool specimens from the AFP cases and contacts were performed according to the World Health Organization (WHO) recommended rhabdomyosarcoma (RD) cells and the human transgenic mouse (L20B) cell lines testing algorithm [23].

A detailed field investigation for the Kamuli and Kween contacts that were identified as VDPVs was immediately conducted by the national rapid response team in close collaboration with district rapid response team to confirm whether there was circulating VDPV or not in these districts. The contact for Kamuli AFP is referred to as VDPV number 1 (VDPV no1) and the contact for Kween AFP is referred to as VDPV number 2 (VDPV no2). In order to determine the etiological and clinical status of AFP cases and contacts, the following were performed: review of the case investigation questionnaires, interview with key persons, detailed clinical examination of the cases, a 30 house-hold clinical survey with stool sampling from the original AFP cases, and contacts to VDPV no. 1 and VDPV no. 2. Furthermore the AFP cases whose contacts had VDPVs were investigated; a visit was made to the major health facilities, traditional healers, and local health authorities. The OPV immunization coverage and AFP surveillance indicator of the affected districts were also reviewed.

Stool specimens were collected from four and five contacts of VDPV no1 and no2 respectively to screen for undetected VDPVs. Two additional stool specimens were collected for poliovirus screening from the VDPV no1 and VDPV no2 within a time of 48 h' at intervals of 28 and 15 days from the time of first virus isolation respectively. One additional stool specimen was collected from the original AFP cases. The s.. All the specimens were transported in a reverse cold chain and investigated for polioviruses in the WHO accredited polio laboratory at Uganda Virus Research Institute (UVRI). Blood specimens were also collected for immunological evaluation from the VDPV no1 and VDPV no2.

\section{Identification of VDPVs using retrospective screening}

A total of 93 Uganda specimens, that had Sabin isolates and were reported 6 months before and 6 months after the 2 VDPVs were retrospectively screened for VDPVs. The viruses that were primarily detected as Sabin 1 and 3 polioviruses were re-screened for the presence of Sabin 2 using a more sensitive Poliovirus rRT-PCR ITD and VDPV 4.0 assays. The viruses that were initially detected as Sabin 2 polioviruses were further characterized by sequencing to rule out the presence of VDPV2.

\section{Virus isolation}

Viral isolation was performed in accordance with the WHO recommended procedures [23]. Briefly, stool specimens were treated with chloroform and $0.2 \mathrm{mls}$ of stool extracts were inoculated into a monolayer of two healthy and confluent (RD) and (L20B) cell lines fed with medium (Eagle's minimum essential media supplemented with $2 \%$ 
fetal calf serum). Characteristic entero-virus cytopatic effect (CPE) was observed within five days of incubation for both extracts. The stool isolates obtained on RD cell line were inoculated on L20B cell line and the isolates obtained on the L20B cell line were inoculated on the RD cell line.

\section{Sabin intra-typic differentiation}

The isolates from the L20B cell line that grew on the RD cell line were further characterized using the poliovirus dual-stage rRT-PCR ITD assay [24]. Basically multiple sets of poliovirus type specific oligonucleotide primers that are tagged with probes were used for intra-typic differentiation (ITD) of the poliovirus as described [25]. In brief $1.0 \mu \mathrm{l}$ of the isolate culture was added to a $24.0 \mu \mathrm{l}$ of the enzyme mixture containing $2.8 \mu \mathrm{l}$ of $1 \mathrm{M}$ DTT, $27.6 \mu \mathrm{l}$ of $40 \mathrm{u} / \mu \mathrm{l}$ of RNase inhibitor, $14.4 \mu \mathrm{l}$ of $25 \mathrm{U} / \mu \mathrm{l}$ of Reverse transcriptase, $54.8 \mu \mathrm{l}$ of $5 \mathrm{U} / \mu \mathrm{l}$ Taq polymerase in $1.0 \mathrm{ml}$ of Buffer B [26]. The isolates that were Sabin-like on ITD screening (the initial assay), were subjected to the VDPV screening (the follow-up assay) to find out whether the viruses were VDPVs or not. The isolates that were 'non-Sabin like' from the VDPV assay suggesting possible VDPVs were referred for confirmatory sequencing to the National Institute of Communicable Diseases (NICD), South Africa.

Re-screening for the Sabin 2 poliovirus among isolates collected before and after detecting the first two VDPVs was performed using the superior ITD/VDPV rRT-PCR 4.0 kit at NICD for those initially detected as Sabin $1+3$ using the dual-stage ITD/VDPV rRT-PCR assay. The samples that had been previously detected as Sabin 2 isolates were sequenced and this was performed at NICD, South Africa.

\section{RNA extraction}

The viral RNA was extracted using the QIAmp Viral RNA manual extraction kit according to the manufacturer's instructions [27].

\section{CDNA and RT-PCR}

The cDNA synthesis reaction of the VP1 region was performed in a $50 \mu \mathrm{l}$ reaction mixture as described [28]); Ten microlitres $(10.0 \mu \mathrm{l})$ of RNA template was added to a PCR mix that comprised of $5.0 \mu \mathrm{l} 10 \times$ PCR buffer, 2 . $0 \mu \mathrm{l}$ of $10 \mathrm{mM}$ dNTP, $1.0 \mu \mathrm{l}$ of Y7R (40picomole/ $\mu \mathrm{l}), 1$. $0 \mu \mathrm{l}$ of Q8 (10picomole/ $\mu \mathrm{l}), 1.0 \mu \mathrm{l}$ of Taq DNA polymerase $(5 \mathrm{U} / \mu \mathrm{l}), 0.5 \mu \mathrm{l}$ RT-AMV $(25 \mathrm{U} / \mu \mathrm{l}, 0.5 \mu \mathrm{l}$ of RNase inhibitor $(40 \mathrm{U} / \mu \mathrm{l})$, and $29.0 \mu \mathrm{l}$ of RNase free water. Reverse transcription (RT) was carried out at $42{ }^{\circ} \mathrm{C}$ for $60 \mathrm{~min}$, followed by the inactivation of the RT enzyme at $94{ }^{\circ} \mathrm{C}$ for $3 \mathrm{~min}$. Amplification consisted of 40 cycles (denaturing at $94{ }^{\circ} \mathrm{C}$ for $30 \mathrm{~s}$, annealing at $42{ }^{\circ} \mathrm{C}$ for $45 \mathrm{~s}$ then ramp at $0.4^{\circ} /$ second to $60{ }^{\circ} \mathrm{C}$ and extension at $60^{\circ}$ $\mathrm{C}$ for $2 \mathrm{~min}$ ).

\section{Gel electrophoresis}

A polymerase chain reaction (PCR) product of $1.1 \mathrm{~kb}$ was run on $1 \%$ agarose gel and the remaining product was purified using QIAquick PCR purification kit [29]. The concentration of the amplified deoxyribonucleic acid (DNA) was measured using the NanoDrop Spectrometer [30] and diluted to a working solution of $20 \mathrm{ng} / \mu \mathrm{l}$ for the sequencing reactions.

\section{Sequencing and data analysis}

Cycle sequencing reaction was performed in a $10 \mu \mathrm{l}$ reaction as follows: $1.0 \mu \mathrm{l}$ of the DNA template was added to the sequencing mix containing $2.0 \mu \mathrm{l}$ of Big Dye Reaction mix, $2.0 \mu \mathrm{l}$ of 5X Sequencing Buffer, $1.0 \mu \mathrm{l}$ of primer 3.2 picomole $/ \mu \mathrm{l}$, and $4.0 \mu \mathrm{l}$ nuclease free water. Amplification consisted of 25 cycles (denaturing at $95{ }^{\circ} \mathrm{C}$ for $15 \mathrm{~s}$, annealing at $42{ }^{\circ} \mathrm{C}$ for $15 \mathrm{~s}$ and extension at $60{ }^{\circ} \mathrm{C}$ for $4 \mathrm{~min}$ ). The sequenced products were purified using the BigDye Xterminator Purification kit (Thermo Fisher Scientific). The following sequencing primers were used: Y7, 246S, 247S, PV2S, PV4S (3.2 picomole/ $\mu$ l) for the sense orientation and Q8, PV10A, PV1A and 253A (3.2 picomole/ $\mu \mathrm{l}$ ) for the antisense orientation [28]. The samples were then run on the ABI 3130xl Genetic analyzer and sequenced. The data were analyzed using Sequencher Software v4.10.1. Finally, the alignment of the sequence data and the inference of phylogenetic relatedness was performed using the MEGA version 7.0 software [31]. The obtained sequences were deposited in the GenBank: MG571532 to MG571534,

\section{Alternative method when amplification was weak}

It was not possible to amplify the virus material from the standard 6 discs from all the filter papers (FTA cards) that were saturated with the inactivated virus on the first attempt. Twelve instead of 6 discs were punched from the FTA cards and resulted in good PCR signals. During the extraction process, the virus might have been exposed to a second inactivation process and could explain the low virus yield that was obtained from the 6 discs.

\section{Results}

Two contacts of two AFP cases from Kamuli and Kween districts of Uganda were both confirmed VDPV2 on 03rd November 2014. In the manuscript, the viruses are identified as VDPV no1 and VDPV no2, respectively. A third VDPV2 from an AFP case was later confirmed on 04th May 2016 from Kisoro district located in Southwestern Uganda in a specimen from a one month old baby. A polio suspected virus was reported on virus culture. The subsequent ITD/VDPV assays displayed a 
VDPV result curve that was misinterpreted and scored a Sabin 2 poliovirus and not a 'possible' VDPV2. As a result the VDPV2 was missed at this stage. The first two contacts were detected during the routine national AFP surveillance activity using the WHO adapted AFP surveillance protocol whereas the third VDPV was detected during the retrospective VDPV screening performed in 2016. Stored frozen isolates of 2014 were investigated. These samples were obtained from cases that were fairly well distributed over the country (Fig. 1).

The characteristics relating to the three aVDPV type 2 from Uganda are shown in Table 1. The 3 aVDPVs were sampled in the 2nd and 3rd quarter of 2014. These aVDPVs type 2 were confirmed from Kamuli and Kween districts in 2014 and from Kisoro district in 2016. Kamuli and Kween are located in the Eastern Uganda 167 and $299 \mathrm{~km}$ from Kampala and $130 \mathrm{~km}$ apart whereas Kisoro is located in the South-western Uganda $481 \mathrm{~km}$ from Kampala. Kampala is the capital city of Uganda characterized with busy travel. The vaccination coverage during 2011, 2012, 2013, and 2014 was not satisfactory for Kamuli, Kween and Kisoro districts. Furthermore the poliovirus AFP surveillance indicators of the non-polio AFP rate and stool adequacy were not satisfactory for the 3 districts (Table 1).

The Kamuli, Kween and Kisoro VDPVs did not share three mutations in the VP1 region. The VDPVs from Kamuli and Kween both contained 6 mutations with a VP1 variation from the reference Sabin of $6.6 \%$. Though these viruses had the same VP1 variation rates they only shared two mutations at the nucleotide level (G308A and T428C) and two mutations at the amino acid level (R103K and I143T). The VDPV from from Kisoro contained 7 mutations with a VP1 variation from the reference Sabin of $7.8 \%$. It shared two mutations at the amino acid level R103K and K160E with Kamuli and Kween and $\mathrm{K} 160 \mathrm{E}$ with Kamuli. At the nucleotide level is shared mutations at G308A, and A505G (Tables 2 and 3). Thus these VDPVs have been categorized as ambiguous VDPVs and not cVDPVs. During 2015 one National Immunization Day (NID) of house to house (HTH) approach and two Sub National Immunisation days (SNID) of HTH were conducted. Furthermore during 2016 one NID and one SNID rounds of OPV immunization were conducted in Kamuli, Kween and Kisoro and other high risk districts [32] to interrupt virus circulation (Fig. 2).

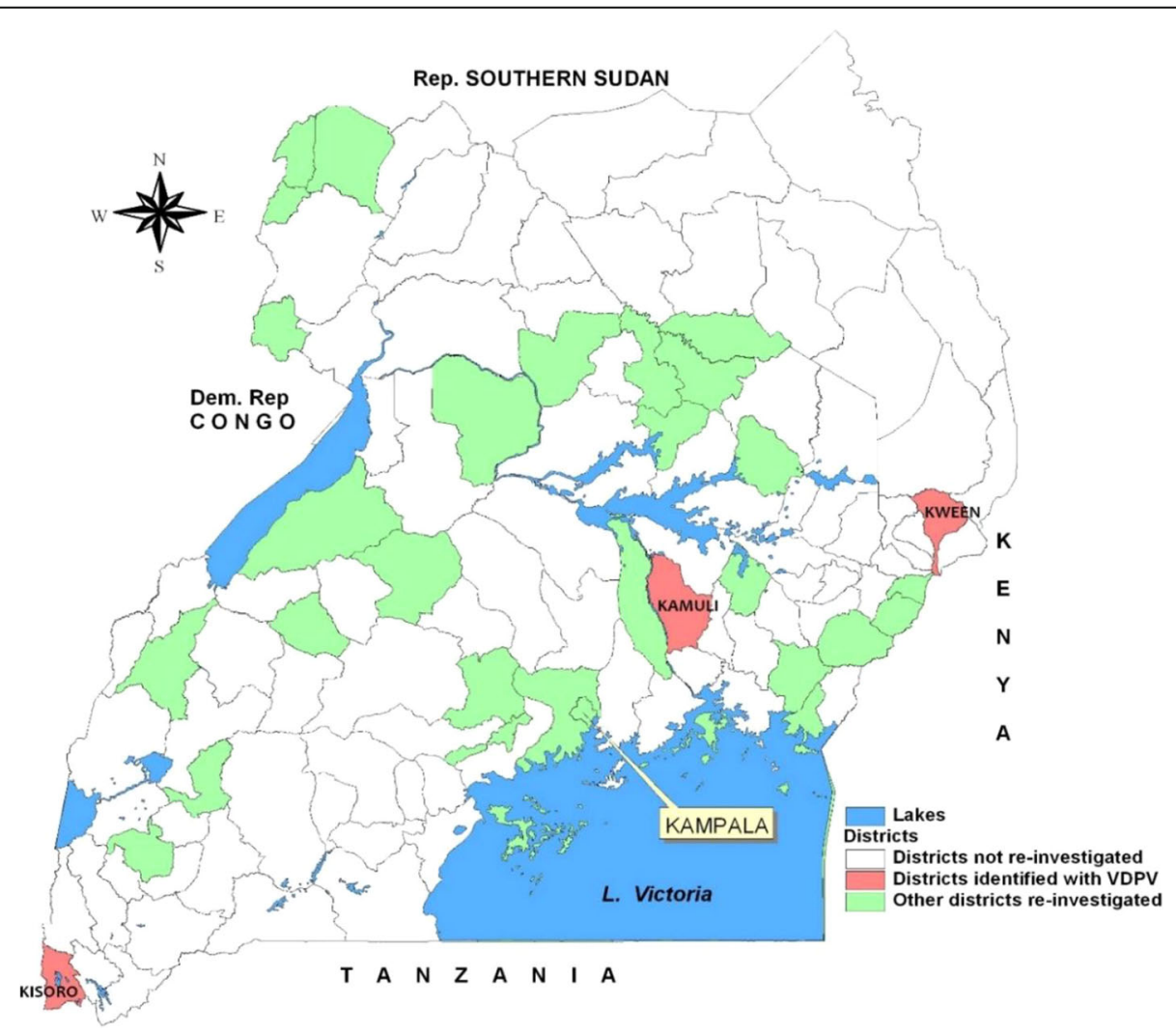

Fig. 1 The districts of Uganda that participated in the VDPV re-screening survey in 2015 to 2016. The above figure is a map of Uganda; the partitioning represents districts further described in the key at the map. The bordering countries are shown: Dem. Rep Congo represents the Democratic Republic of Congo and Rep. Southern Sudan represents the Republic of Southern Sudan 
Table 1 Characteristics of aVDPVs from Kamuli, Kween, and Kisoro districts of Uganda

\begin{tabular}{|c|c|c|c|c|c|}
\hline & aVDPV (contact 1) & AFP case 1 & aVDPV (contact 2) & AFP case 2 & aVDPV (primary) \\
\hline Place of isolation & \multicolumn{2}{|c|}{$\begin{array}{l}\text { Kamuli, } 167 \text { km from } \\
\text { Kampala, Eastern Uganda }\end{array}$} & \multicolumn{2}{|c|}{$\begin{array}{l}\text { Kween, } 299 \mathrm{~km} \text { from } \\
\text { Kampala, Eastern Uganda }\end{array}$} & $\begin{array}{l}\text { Kisoro } 481 \mathrm{~km} \text { from } \\
\text { Kampala, South-western } \\
\text { Uganda, borders DRC }\end{array}$ \\
\hline $\begin{array}{l}\text { Date of onset of paralysis } \\
\text { (AFP case) }\end{array}$ & & 13th Aug 2014 & & 28th Jul 2014 & 18th May 2014 \\
\hline $\begin{array}{l}\text { Date of laboratory confirmation } \\
\text { of VDPV }\end{array}$ & \multicolumn{2}{|l|}{ 03rd Nov 2014} & \multicolumn{2}{|l|}{ 03rd Nov 2014} & 04th May 2016 \\
\hline OPV dose history & 1 & - & 4 & 2 (1 and 3) & 4 \\
\hline Last OPV dose & 02nd Jul 2014 & - & 18th Dec 2012 & 20th Nov 2012 & February 2015 \\
\hline Card seen? & Yes & - & Yes & Yes & - \\
\hline CD4 count $/ \mu \mathrm{l}$ & 2548 & 3467 & 1417 & 1470 & Note done \\
\hline Age (months) & 4 & 39 & 24 & 26 & 1 \\
\hline Sex & M & M & M & $\mathrm{F}$ & $\mathrm{F}$ \\
\hline $\begin{array}{l}\text { Stool conditions for the original } \\
\text { specimens }\end{array}$ & $\begin{array}{l}\text { One specimen } \\
\text { delivered at } 4-8{ }^{\circ} \mathrm{C}\end{array}$ & $\begin{array}{l}\text { Two specimens } \\
\text { delivered at } 4-8{ }^{\circ} \mathrm{C}\end{array}$ & $\begin{array}{l}\text { One specimen } \\
\text { delivered at } 4-8{ }^{\circ} \mathrm{C}\end{array}$ & $\begin{array}{l}\text { Two specimens } \\
\text { delivered at } 4-8{ }^{\circ} \mathrm{C}\end{array}$ & $\begin{array}{l}\text { Two specimens } \\
\text { delivered at 4-80C }\end{array}$ \\
\hline Relationship to the AFP case & \multicolumn{2}{|l|}{ Sibling } & \multicolumn{2}{|l|}{ Not specified } & Not applicable \\
\hline Injection given (date) & & $\begin{array}{l}11 \& 12 \text { th Aug } \\
2014\end{array}$ & & aseptember 2013 & none \\
\hline Diagnoses for the AFP case & & $\begin{array}{l}\text { Injection neuritis, } \\
\text { left leg }\end{array}$ & & $\begin{array}{l}\text { Injection neuritis, } \\
\text { right leg }\end{array}$ & $\begin{array}{l}\text { Congenital abnormality, } \\
\text { left arm }\end{array}$ \\
\hline $\begin{array}{l}\text { On 60th day follow up of the } \\
\text { AFP case }\end{array}$ & & $\begin{array}{l}\text { Completely } \\
\text { recovered }\end{array}$ & & $\begin{array}{l}\text { Limp gait, right } \\
\text { leg }\end{array}$ & Not done \\
\hline $\begin{array}{l}\text { Proportion of cases ( } 6 \text { months } \\
\text { to } 15 \text { years) with OPV3+ } \\
\text { immunisation status } \geq 80 \%\end{array}$ & \multicolumn{2}{|l|}{$\begin{array}{l}2011-75 \% \\
2012-67 \% \\
2013-100 \% \\
2014--\end{array}$} & \multicolumn{2}{|l|}{$\begin{array}{l}67 \% \\
60 \% \\
50 \% \\
-\end{array}$} & $\begin{array}{l}0 \% \\
100 \% \\
38 \% \\
-\end{array}$ \\
\hline Non polio AFR rate $(\geq 4 / 100,000)$ & \multicolumn{2}{|l|}{$\begin{array}{l}2011-1.59 \\
2012-1.22 \\
2013-0.79 \\
2014-2.09\end{array}$} & \multicolumn{2}{|l|}{$\begin{array}{l}5.83 \\
19.76 \\
22.99 \\
18.27\end{array}$} & $\begin{array}{l}1.53 \\
3.2 \\
6.23 \\
6.60\end{array}$ \\
\hline Stool adequacy $\geq 80 \%$ & \multicolumn{2}{|l|}{$\begin{array}{l}2011-75 \% \\
2012-67 \% \\
2013-50 \% \\
2014-20 \%\end{array}$} & \multicolumn{2}{|l|}{$\begin{array}{l}92 \% \\
100 \% \\
50 \% \\
89 \%\end{array}$} & $\begin{array}{l}0 \% \\
100 \% \\
63 \% \\
88 \%\end{array}$ \\
\hline Father's occupation & \multicolumn{2}{|l|}{ Businessman } & \multicolumn{2}{|l|}{ Businessman } & Peasant \\
\hline Mother's occupation & \multicolumn{2}{|l|}{ Housewife } & \multicolumn{2}{|l|}{-} & - \\
\hline Residence population & \multicolumn{2}{|l|}{ Densely populated } & \multicolumn{2}{|c|}{ Clusters of home steads } & $\begin{array}{l}\text { Spaced clusters of } \\
\text { home steads }\end{array}$ \\
\hline Landscape & \multicolumn{2}{|l|}{ Flat } & \multicolumn{2}{|l|}{ Mountainous terrain } & Steep mountainous \\
\hline $\begin{array}{l}\text { Visitors that came to the } \\
\text { home recently }\end{array}$ & & few & & numerous & - \\
\hline Clean water source & \multicolumn{2}{|l|}{ No running water } & \multicolumn{2}{|l|}{ No running water } & $45 \%$ have clean water \\
\hline Vaccine supply & \multicolumn{2}{|l|}{ Not regular } & \multicolumn{2}{|l|}{-} & Regular \\
\hline Sanitation & \multicolumn{2}{|l|}{ Poor conditions } & \multicolumn{2}{|l|}{ Poor conditions } & Good conditions \\
\hline 30 household survey & \multicolumn{2}{|c|}{$50 \%$ had received OPV for their age } & \multicolumn{2}{|c|}{$\begin{array}{l}62 \% \text { of the households surveyed had } \\
\text { been fully immunised for poliovirus }\end{array}$} & Not done \\
\hline $\begin{array}{l}\text { Health seeking behaviour of the } \\
\text { community }\end{array}$ & \multicolumn{2}{|c|}{$\begin{array}{l}\text { Poor, negative beliefs about } \\
\text { immunization }\end{array}$} & \multicolumn{2}{|c|}{$\begin{array}{l}\text { Poor health seeking behaviour, does } \\
\text { not honour medical appointments }\end{array}$} & $\begin{array}{l}\text { Good health seeking } \\
\text { behaviour, seeks } \\
\text { for treatment }\end{array}$ \\
\hline
\end{tabular}

The table shows the identifiers, personal characteristics, vaccine coverage, and AFP surveillance indicators for the 3 VDPVs that have been detected in Uganda

athe exact date of receiving the injection not known, and -: the information was not available 
Table 2 Nucleotide mutations that were identified in the VP1 region of the Sabin polioviruses

\begin{tabular}{|c|c|c|c|c|c|c|c|c|c|c|c|c|c|c|c|c|c|}
\hline Position of mutation & 156 & 165 & 180 & 279 & 308 & 316 & 420 & 427 & 428 & 432 & 505 & 516 & 534 & 645 & 819 & 828 & 885 \\
\hline Sabin 2 reference & C & G & $C$ & C & G & $\mathrm{T}$ & A & A & $\mathrm{T}$ & $\mathrm{T}$ & A & $C$ & $C$ & A & $\mathrm{T}$ & A & A \\
\hline Bugiri 2 & & & & & & & & & C & & & & & & & & G \\
\hline Hoima 1 & & & & & & & & & $Y$ & & & & & & & & \\
\hline Yumbe 1 & & & & & & & G & G & & & & & & & & & \\
\hline Yumbe 2 & & & & & & & G & G & & & & & & & & & \\
\hline Kiryandongo 1 & & & & & & & & & C & & & & & & & & \\
\hline Kiryandongo 2 & & & & & & & & & C & & & & & & & & \\
\hline Kisoro (VDPV) & & & & & ${ }^{\mathrm{a}} \mathbf{A} / \mathrm{G}$ & & & ${ }^{\mathrm{a}} \mathbf{G} / \mathrm{A}$ & & ${ }^{\mathrm{a}} \mathrm{A} / \mathrm{T}$ & ${ }^{\mathrm{a}} \mathrm{G} / \mathrm{A}$ & ${ }^{\mathrm{a}} \mathrm{T} / \mathrm{C}$ & ${ }^{\mathrm{a}} \mathrm{T} / \mathrm{C}$ & ${ }^{a} \mathrm{G} / \mathrm{A}$ & & & \\
\hline Kamuli 2 (VDPV) & $\mathrm{T}$ & & A & & A & & & & C & & G & & & & C & & \\
\hline Kween (VDPV) & & A & & $\mathrm{T}$ & A & G & & & C & & & & & & & C & \\
\hline Mananfwa 1 & & & & & & A & & & & & & & & & & & \\
\hline Frequency of nucleotide mutations & 1 & 1 & 1 & 1 & 3 & 2 & 1 & 3 & 6 & 1 & 2 & 1 & 1 & 1 & 1 & 1 & 1 \\
\hline
\end{tabular}

A bold letter represents $\geq 3$ nucleotide mutations at the corresponding position

a: mixed nucleotide site; $\mathrm{A}$ or $\mathrm{C}$ or $\mathrm{G}$ or T are abbreviations, $A$ Adenine, $C$ Cytosine, $G$ Guanidine and $T$ Thymidine. $Y$ represents $C$ or T. The names in the first column are districts of Sabin 2 and VDPV origin

A review of the Sabin poliovirus 2 characteristics showed that out of the 19 cases; $21.4 \%$ were VDPVs, 42. 9\% were VRPVs and $35.7 \%$ were non-mutant Sabin polioviruses 2. The point mutations that were observed for Sabin 2 were: C156T, G165A, C180A, C279T, G308A, T316G, T428C, A505G, T819C, and A828C (Table 2). Substitutions G308A, T428C, and A505G were common in VDPVs. The mutation sites G308A and T428C were common to the Kamuli and Kween VDPVs. The Kisoro VDPV contained mixed bases at 7 positions (Table 2).

The amino acid substitutions in the VP1 region of the Sabin mutants are further shown in Table 3.

All the VDPVs contained the G308A and R103K nucleotide and amino acids substitutions respectively (Tables 2 and 3). The common amino acid mutations for the VDPV were K169E for Kamuli and Kisoro and I143T together with R103K for Kamuli and Kween districts. The phylogeny of the aVDPV type 2 reported for Democratic Republic of Congo (DRC), Nigeria and Madagascar was constructed and shown (Fig. 3). The Uganda (UGA) VDPVs were less divergent representing a short evolution period.

Ninety-nine percent, (92 out of 93) of the specimens from the AFP cases that were re-screened for Sabin 2 and VDPV2 in the retrospective VDPV study and the 4 and 5 secondary contacts of VDPVs no1 and no2 were negative for the serotype 2 polioviruses. One specimen was collected from the original AFP cases on follow-up and also one specimen from the secondary contacts which could have compromised on virus recovery. Only one virus out of the 93 was a type 2 poliovirus that had not been detected initially. Results from poliovirus dualstage rRT-PCR ITD/VDPV kit that was used for the index testing and the ITD rRT-PCR 4.0 kit that was used for the re-screening were concordant; previously detected Sabin 2 polioviruses were not re-run on ITD but were sequenced to screen for VDPV2s. Only one VDPV type 2 from the previously detected Sabin 2 polioviruses was identified on the second screening.

\section{Discussion}

The three VDPVs shared the R103K mutation that could be linked to a natural selection process. The mutation I143T was common to Kamuli and Kween and has been reported in all the polioviruses that were detected from stool specimens of AFP cases in an Afghanistan study [5]. The nucleotide mutation T428C was the most frequent mutation among the studied viruses, which is consistent with the previous reports in the scientific literature. The $\mathrm{T} 428 \mathrm{C}$ mutation may have a pivotal role in VDPV2 evolution. The VDPV cases from Kamuli and Kween originated from immune-competent persons with normal CD4 cell counts compatible with the aVDPV

Table 3 The amino acid mutations in the VP1 region of the 3 aVDPVs type 2

\begin{tabular}{llllll}
\hline Amino acid substitution in VP1 & ${ }^{a}$ R103K & S106A & {$\left[{ }^{a} 11437\right]$} & I143V & D144E \\
\hline VDPVs & Kamuli & & Kamuli & & K169E \\
& Kisoro & & & Kisoro & Kisoro \\
& Kween & Kween & Kween & & Kisoro \\
\hline
\end{tabular}

The amino acid mutations in the VP1 of the 3 VDPVs from the 3 districts of Uganda are shown

arepresents substitution identified in more than one VDPVs; []: neuro-virulence determinant within the antigenic site [41] 


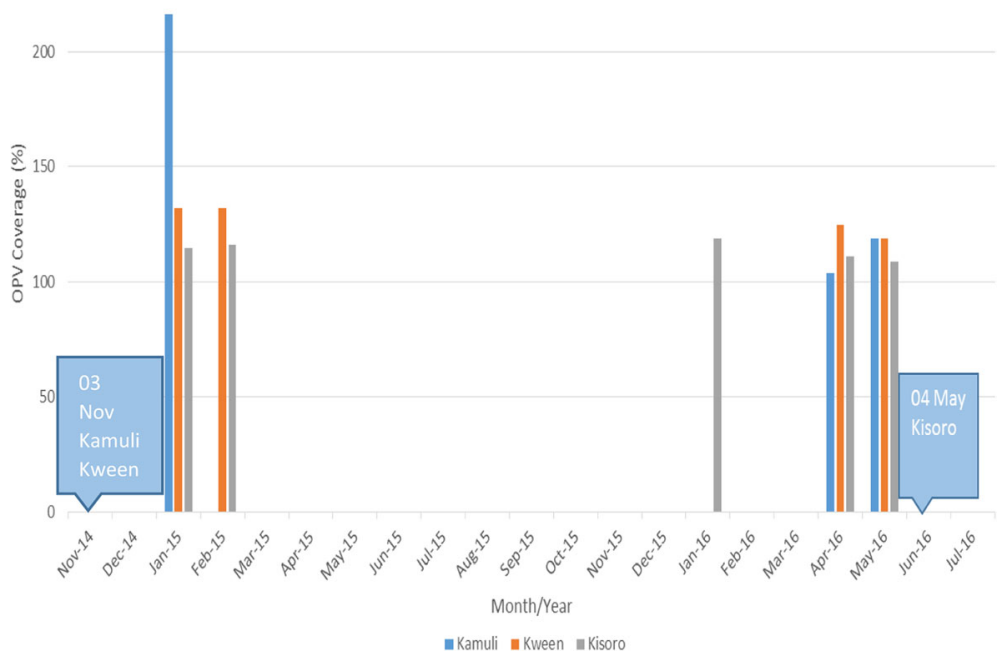

Fig. 2 Enhancing population OPV immunity following VDPV detection in Uganda. The rectangle represents the date of VDPV detection. The bars in different colors represent vaccination coverage in the various districts where the VDPVs were identified. In Kisoro district the intervention was performed in April 2016 following a risk assessment that was conducted before the detection of the VDPV

classification. Vaccine-derived polioviruses have been reported elsewhere in African countries namely DRC, Angola, Egypt, Nigeria, and Sudan [16, 33] and now VDPVs identified in Uganda for the first time.

The wild poliovirus 2 was eradicated ahead of wild poliovirus 1 and 3. Wild Poliovirus 1 (WPV1) and Wild Poliovirus 3 (WPV3) are being eradicated later because the OPV1 and 3 are less immunogenic than OPV2 [34]. In order to overcome the challenge of a lower immunogenicity, a more immunogenic bivalent vaccine has been developed for OPV 1 and 3. It has already been introduced in the routine OPV immunization schedule and OPV 2 has been withdrawn from the trivalent OPV. Trivalent OPV (tOPV) previously contained OPV type 1, OPV type 2 and OPV type 3 and now a bivalent OPV (bOPV) which contains OPV type 1 and OPV type 3. Since 1999, no cases of Wild Poliovirus 2 (WPV2) have been reported globally and OPV2 included in tOPV has continued to cause VDPV type 2 infections. A switch from tOPV2 to bOPV and Inactivated Polio Vaccine (IPV) has been adopted as a mitigation measure against VDPV type 2 infections [35, 36].

The third VDPV was from a baby in Kisoro district and contained mixed bases characteristic of iVDPV [37, 38]. Unfortunately, the immune status of the child could not be established because she died before the follow-up visit following a respiratory disease. The evolution of VP1 accumulate at a rate of $1 \%$ per year therefore this VDPV could have been from an exogenous source. It could not be established whether the VDPV came from a family member or not because the virus was confirmed late. Confirmation by performing a repeat stool test was also not possible because the sample had been destroyed in accordance with the WHO programmatic recommendations for type 2 containment. The poliovirus immunization and the surveillance indicators for Kisoro district were not satisfactory. Kisoro has a steep mountainous landscape and a constrained accessibility to the provider services could explain the inadequate performance. The DRC that has reported VDPVs borders Uganda. Kisoro is closest to DRC in southwestern Uganda and thus Kisoro is a high risk area by vicinity and restricted accessibility In view of the high risk exposure for Kisoro the national EPI program enhanced the polio vaccination in Kisoro district to safe guard against virus importation. It is commendable that by the time of reporting this VDPV, the high risk for VDPVs in Kisoro district had been pre-determined and corrective actions had already been taken. The 3 districts and country at large need to be closely monitored to enhance population immunity and prevent re-occurrences. VDPVs can be identified in low risk areas among subpopulations with low immunity and in recipients with no known immune deficiencies [33]. Eradicating of VDPVs remain a priority in both the high and low risk populations.

In the 2014-2015 VDPV rescreening, a survey was conducted in 33 district and 93 AFP cases were tested; nineteen $(20.4 \%)$ were Sabin poliovirus 2, 28 (30.1\%) Sabin poliovirus 1 and 46 (49.5\%) were Sabin poliovirus 3. Sabin 2 was least prevalent which is not surprising because OPV2 is more immunogenic than OPV1 +3 . However what is surprising, VDPV2s are more common than VDPV1 or 3 . The Sabin 2 poliovirus could be associated with sub-optimal secondary excretion or spread which result in partial secondary immunization giving a chance to 


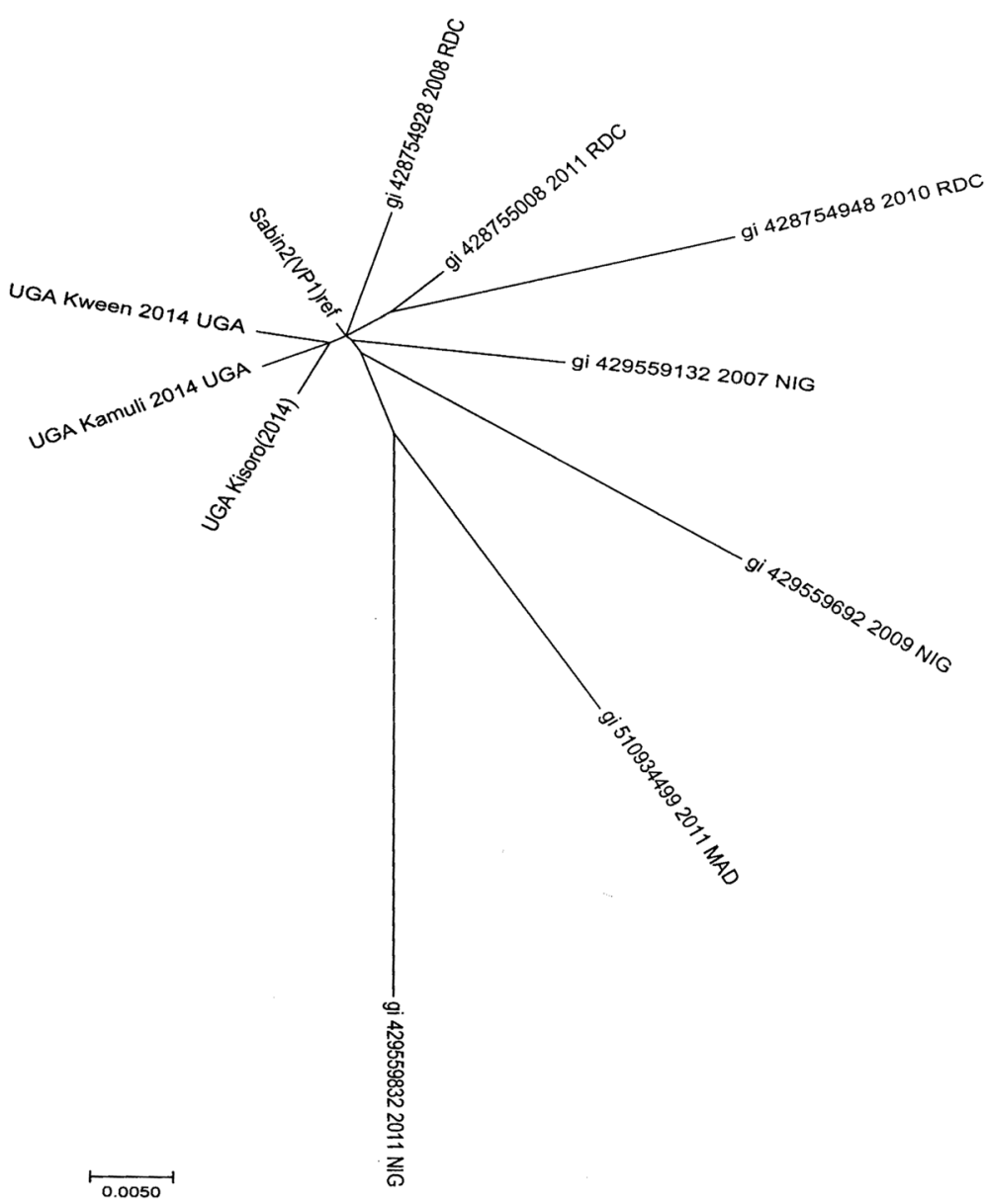

Fig. 3 The Phylogeny of VDPVs from Uganda, Republic of Democratic Congo (RDC/DRC), Nigeria and Madagascar. The diagram is a VP1 radiation phylogeny for 4 African countries. The VP1 sequences are denoted by the accession codes of the gene bank. The years of identification are included too. Sabin 2 is the parent and reference sequence. UGA stands for Uganda, RDC - Republic of Democratic Congo, NIG - Nigeria and MAD - Madagascar

the virus to evolve. Understanding more about the Sabin poliovirus 2 evolution remains an important area for investigation and could enhance the understanding of the pathogenesis of the live attenuated vaccines [39].

The emergence of VDPVs under ideal good hygienic conditions, high IPV coverage and high population immunity has not been demonstrated [40] however, these parameters differ especially in the developing countries and need to be considered. In Uganda the risk of VDPVs has been attributed to the inadequate vaccination coverage and surveillance system together with possible proximity to an endemic area. The national immunization program responded exceptionally well, with targeted vaccination and intensified AFP surveillance.

\section{Conclusion}

One additional isolate was confirmed an aVDPV during the VDPV survey. The VDPV survey enhanced VDPV detection in the country.

\section{Additional files}

Additional file 1: Recommendation for publication. Recommendation from the Ministry of Health. (PDF $42 \mathrm{~kb}$ )

Additional file 2: Consent to manuscript content and creative commons public license, Approvals from the co-authors. (PDF $116 \mathrm{~kb})$

Additional file 3: The Phylogeny of VDPVs from Uganda, Republic of Democratic Congo (RDC/DRC), Nigeria and Madagascar. (PDF 140 kb)

\section{Abbreviations}

AFP: Acute flaccid paralysis; aVDPV: Ambiguous vaccine-derived poliovirus; AVL: Virus lysis buffer; AW1: Stringent wash buffer; AW2: Salt wash buffer; cVDPV: Circulating vaccine-derived poliovirus; DNA: Deoxyribonucleic acid; DRC: Democratic Republic of Congo; EB: Elution buffer; HTH: House to house; IPV : Inactivated poliovirus vaccine; ITD rRT-PCR: Intratypic differentiation ribonucleic acid reverse transcription polymerase chain reaction; iVDPV: Immunodeficiency-associated vaccine-derived poliovirus; L20B: Human transgenic mouse cell line; NID: National immunisation day; OPV: Oral polio vaccine; Q8: Antisense primer for VP1;

RD: Rhabdomyosarcoma cell line; RDC = DRC: Republic of Democratic Congo; RNA: Ribonucleic acid; SNID: Sub National Immunisation Day; UGA: Uganda; UVRI: Uganda Virus Research Institute; VDPV rRT-PCR: Vaccine-derived poliovirus ribonucleic acid reverse transcription polymerase chain reaction; VDPV: Vaccine-derived poliovirus; VP1: Virus surface protein 1; VRPV: Virus- 
related poliovirus; WHO: World Health Organization; WPV1: Wild Poliovirus 1; WPV2: Wild Poliovirus 2; WPV3: Wild Poliovirus 3; Y7: Sense primer for VP1

\section{Acknowledgements}

Data collection: Ministry of Health, the United Nations Children's Fund (UNICEF) and WHO team in Uganda, Joseph Gaizi and Ronald Seguya; Data handling: Proscovia Kakooza, Molly Birungi and Nasan Natseri; virus isolation: Apollo Thomas and Ronald Seguya; sequencing: Lerato Seakaemela and Wayne Howard. We thank Cara Burns for her critical review and we also extend special thanks to the participants who have made it possible to perform this work.

\section{Funding}

WHO funds were provided for AFP surveillance. The organization contributed to the data collection and laboratory activities.

\section{Availability of data and materials}

All data generated or analyzed during this study are included in this published article and Additional files 1, 2 and 3.

\section{Authors' contributions}

$\mathrm{BB}, \mathrm{CRB}$ and NMG: composed the idea; AK, EK: handled the data; HB: performed virus isolation; $\mathrm{PN}$ and $\mathrm{MBN}$ : performed intra-typic differentiation assays; MBN and RW: performed sequencing; MBN and NMG: analyzed data; MBN: major contributor to writing; $B B, A K, P N, H B, E K, J B, C R B, R W$ and NMG: reviewed and edited the manuscript. All authors approved the manuscript (Additional file 2).

\section{Ethics approval and consent to participate}

Not applicable.

\section{Consent for publication}

Additional file 1.

\section{Competing interests}

The authors declare that they have no competing interests

\section{Publisher's Note}

Springer Nature remains neutral with regard to jurisdictional claims in published maps and institutional affiliations.

\section{Author details}

${ }^{1}$ Uganda Virus Research Institute (UVRI), Plot 51 - 59 Nakiwogo Road, P. O. Box 49, Entebbe, Uganda. ${ }^{2}$ World Health Organization (WHO), Plot 60 Prince Charles Avenue, KololoP.O. Box 24578, Kampala, Uganda. ${ }^{3}$ WHO Intercountry Office, Harare, Zimbabwe. ${ }^{4}$ National Institute for Communicable Diseases (NICD), 1 Modderfontein Road Sandringham Johannesburg. Private Bag x4, Sandringham 2131, South Africa. ${ }^{5}$ NSW HIV State Reference Laboratory, St Vicent's Hospital, Darlinghurst, NSW 2010, Australia. ${ }^{6}$ World Health Organization, Regional Office for Africa, P.O. Box 06, Brazzaville, Republic of Congo.

\section{Received: 18 January 2018 Accepted: 19 April 2018}

\section{Published online: 27 April 2018}

\section{References}

1. EA C. Spread of vaccine-derived poliovirus from a paralytic case in an Immunodeficient child: an insight into the natural evolution of oral polio vaccine. Virology. 2005;

2. Burns CC, et al. Vaccine-derived polioviruses. J Infect Dis. 2014;210(Suppl 1): S283-93.

3. Wassilak S, et al. Outbreak of type 2 vaccine-derived poliovirus in Nigeria: emergence and widespread circulation in an underimmunized population. J Infect Dis. 2011;203(7):898-909.

4. World Health Organization. Laboratory surveillance for wild and vaccine-derived polioviruses, January 2003-June 2004. Wkly Epidemiol Rec. 2004;79:393-399.

5. Sharif $\mathrm{S}$, et al. Evolution and circulation of type-2 vaccine-derived polioviruses in Nad Ali district of southern Afghanistan during June 2009February 2011. PLoS One. 2014;9(2):e88442.

6. Jorba J. Phylogenetic analysis of poliovirus sequences. Methods Mol Biol. 2016;1387:227-37
7. Kew OM, et al. Vaccine-derived polioviruses and the endgame strategy for global polio eradication. Annu Rev Microbiol. 2005;59:587-635.

8. Alexander JP Jr, Gary HE Jr, Pallansch MA. Duration of poliovirus excretion and its implications for acute flaccid paralysis surveillance: a review of the literature. J Infect Dis. 1997;175(Suppl 1):S176-82.

9. Bennett JE, Dolin R, Blaser MJ. Principles and practice of infectious diseases: Elsevier Health Sciences, 8th Edition; 2014.

10. Organization, W.H. Summary of discussions and recommendations, 16th informal consultation of the global polio laboratory network, 22-23 September 2010. In: WHO/HQ. Geneva: World Health Organization; 2010.

11. Centers for Disease Control and Prevention (CDC). Update on vaccinederived polioviruses-worldwide, July 2009-March 2011. MMWR Morb Mortal Wkly Rep. 2011:60(25):846-50.

12. Center for disease control and prevention (CDC). Update on VaccineDerived Polioviruses - Worldwide, January 2008-June 2009 September 18. 2009;58(36):1002-1006.

13. Organization, W.H. Global Polio Eradication Initiative: Polio Eradication and Endgame Strategic Plan (2013-2018). Geneva: Report No, WHO/POLIO/13. 02; 2013.

14. Gumede N, Muthambi V, Schoub BD. Immunodeficiency-associated vaccinederived poliovirus type 3 in infant, South Africa, 2011. Emerg Infect Dis. 2012;18(6):992-4.

15. Kim JH, Rho SH. Transmission dynamics of oral polio vaccine viruses and vaccine-derived polioviruses on networks. J Theor Biol. 2015;364:266-74.

16. Gumede N, et al. Emergence of vaccine-derived polioviruses, Democratic Republic of Congo, 2004-2011. Emerg Infect Dis. 2013;19(10):1583-9.

17. Troy SB, et al. Community circulation patterns of oral polio vaccine serotypes 1, 2, and 3 after Mexican national immunization weeks. J Infect Dis. 2014;209(11):1693-9.

18. Garon JR, Cochi SL, Orenstein WA. The challenge of global poliomyelitis eradication. Infect Dis Clin N Am. 2015;29(4):651-65.

19. Center for Disease Control and Prevention (CDC). Update on vaccinederived polioviruses-worldwide, January 2006-August 2007. MMWR. 2007; 56(38):996-1001.

20. Center for Disease Control and Prevention (CDC). Update on vaccinederived polioviruses-worldwide, April 2011-June 2012. MMWR Morb Mortal Wkly Rep. 2012;61:741

21. Diop OM, et al. Update on vaccine-derived polioviruses-worldwide, January 2014-march 2015. MMWR Morb Mortal Wkly Rep. 2015;64(23):640-6.

22. Buttinelli $G$, et al. Nucleotide variation in Sabin type 2 poliovirus from an immunodeficient patient with poliomyelitis. J Gen Virol. 2003;84(Pt 5): 1215-21.

23. World Health Organisation, Polio Laboratory Manual, 4th Edition; 2004

24. Kilpatrick DR, et al. Identification of vaccine-derived polioviruses using dualstage real-time RT-PCR. J Virol Methods. 2014;197:25-8.

25. Kilpatrick DR, et al. Rapid group-, serotype-, and vaccine strain-specific identification of poliovirus isolates by real-time reverse transcription-PCR using degenerate primers and probes containing deoxyinosine residues. J Clin Microbiol. 2009:47(6):1939-41.

26. Taniuchi $M$, et al. Kinetics of poliovirus shedding following oral vaccination as measured by quantitative reverse transcription-PCR versus culture. J Clin Microbiol. 2015;53(1):206-11.

27. Qiagen, QIAamp Viral RNA Mini Kit. https://www.qiagen.com/us/shop/ sample-technologies/rna/viral-rna/qiaamp-viral-rna-mini-kit/ \#orderinginformation.

28. Kilpatrick DR, et al. Poliovirus serotype-specific VP1 sequencing primers. J Virol Methods. 2011;174(1-2):128-30.

29. Qiagen, QIAquick PCR Purification Kit. https://www.qiagen.com/us/shop/ sample-technologies/dna/dna-clean-up/qiaquick-pcr-purification-kit/ \#orderinginformation.

30. Scientific, T.F., NanoDrop ${ }^{\mathrm{TM}}$ 2000/2000c Spectrophotometers. https://www. thermofisher.com/order/catalog/product/ND-2000.

31. Kumar S, Stecher G, Tamura K. MEGA7: molecular evolutionary genetics analysis version 7.0 for bigger datasets. Mol Biol Evol. 2016;33(7):1870-4

32. Sunrise, Mass Polio immunisation campaign on in 57 districts; 2016. http:// www.sunrise.ug/category/opinions/editorial.

33. Diop OM, et al. Update on vaccine-derived polioviruses-worldwide, July 2012-December 2013. MMWR Morb Mortal Wkly Rep. 2014;63(11):242-8.

34. Patriarca PA, Wright PF, John TJ. Factors affecting the immunogenicity of oral poliovirus vaccine in developing countries. Rev Infect Dis. 1991;13(5): 926-39. 
35. Hampton LM. Introduction of inactivated poliovirus vaccine and switch from trivalent to bivalent oral poliovirus vaccine-worldwide, 2013-2016. MMWR-Morbidity mortality weekly report. 2015;64(25):699-702.

36. Garon J, et al. Polio endgame: the global switch from tOPV to bOPV. Expert Rev Vaccines. 2016;15(6):693-708.

37. Al-Hello $\mathrm{H}$, et al. Highly divergent type 2 and 3 vaccine-derived polioviruses isolated from sewage in Tallinn, Estonia. J Virol. 2013;87(23):13076-80.

38. Shahmahmoodi S, et al. Isolation of a type 3 vaccine-derived poliovirus (VDPV) from an Iranian child with X-linked agammaglobulinemia. Virus Res. 2008;137(1):168-72.

39. Famulare $M$, et al. Sabin vaccine reversion in the field: a comprehensive analysis of Sabin-like poliovirus isolates in Nigeria. J Virol. 2016;90(1):317-31.

40. Wahjuhono $\mathrm{G}$, et al. Switch from oral to inactivated poliovirus vaccine in Yogyakarta Province, Indonesia: summary of coverage, immunity, and environmental surveillance. J Infect Dis. 2014;210(suppl_1):S347-52.

41. Tao $Z$, et al. Isolation and characterization of a type 2 vaccine-derived poliovirus from environmental surveillance in China, 2012. PLoS One. 2013; 8(12):e83975.

Ready to submit your research? Choose BMC and benefit from:

- fast, convenient online submission

- thorough peer review by experienced researchers in your field

- rapid publication on acceptance

- support for research data, including large and complex data types

- gold Open Access which fosters wider collaboration and increased citations

- maximum visibility for your research: over $100 \mathrm{M}$ website views per year

At BMC, research is always in progress.

Learn more biomedcentral.com/submissions 